\title{
Post-9/11 Melancholic Identities: Memory, Mourning and National Consciousness
}

\author{
Aroosa Kanwal \\ Department of English, International Islamic University, Islamabad, Pakistan \\ aroosa.kanwal@iiu.edu.pk
}

\begin{abstract}
This paper discusses the ways in which Nadeem Aslam's novels - Maps for Lost Lovers and The Wasted Vigil - highlight the need for a reconceptualisation of immigrant identity, in post-9/11 world, by linking traumatic experiences of an individual to the collective memory of a community or nation. Taking cue from Sigmund Freud, Judith Butler, Nicolas Abraham and Maria Torok's concepts of mourning and melancholia, an interface between transnational movement and mourning will be investigated in order to emphasise how private grief becomes a metaphor for public grief. With reference to Aslam's novels (that are set against the background of post-9/11 rhetoric of war on terrorism), I discuss how an endless process of diasporic nostalgia and mourning interacts with immigrants' efforts to deal with different 'others' in their adopted homelands.
\end{abstract}

Keywords

Mourning; Melancholia; Trauma; Transnational Movement; National Consciousness.

Article Received: 10 August 2020, Revised: 25 October 2020, Accepted: 18 November 2020

\section{Introduction}

This paper is an attempt to demonstrate that Nadeem Aslam's novels - Maps for Lost Lovers(2004) and The Wasted Vigil (2008) - highlight the need for a reconceptualisation of immigrant identity by linking traumatic experiences of an individual to the collective memory of a community or nation. Drawing on Freud, Butler, Abraham and Torok's concepts of mourning and melancholia, an interface between transnational movement and mourning will be investigated in order to emphasise how private grief becomes a metaphor for public grief. With reference to Aslam's work, (that are set against the background of post9/11 rhetoric of waron terrorism) I show how an endless process of diasporicnostalgia and mourning interacts with immigrants' efforts to deal with different others. Maps for Lost Lovers is a story of the British Pakistani community and families at the crossroads of liberalism and orthodoxy. At the heart of the novel, Chanda and Jugnu, on their return from Pakistan to Dasht-e-Tanhai - an unspecified fictional town in the north England -are missing. The police suspect that this is a case of honour killing and arrest Chanda's brothers. In the midst of this gloominess, we encounter Kaukab, her husband Shamas, and their three estranged and westernised children - MahJabin, Ujala and Charagh - awaiting the killers' trial. Torn between her religious orthodoxy and her husband's and children's liberalism and in order to prove herself a loving mother and a caring wife, Kaukab makes a great effort to distance herself from a "dirty country, an un-sacred country full of people with disgusting habits and practices," but her dilemma is that she could never prevent her children from assimilating into "[t]he decadent and corrupt West" (63). Shamas falls in love with a newly divorced woman, Suraya, who tries to seduce Shamas into a quick marriage so that she may take divorce and go back to her former husband.
In Maps for Lost Lovers, Kaukab's inability to come to terms with the place in which she is living turns her in to a melancholic who, according to Freud, "vilifies [her] self and expects to be cast out and punished" (Gay 1995, 584). In "Mourning and Melancholia", highlighting the symptoms of what he calls psychogenic melancholia, Freud argues:

"Where there is a disposition to obsessional neuros is the conflict due to ambivalence gives a pathological cast to mourning and forces it to express itself in the form of selfreproaches to the effect that the mourner himself is to blame for the loss of the loved object" (Gay 1995, 587-588). In the case of Kaukab, this loved object is her Sohni Dharti, her homeland. Kaukab's lamentations with regards to immigration to the UK involve such self-reproaches: "If I tell you something everyday it's because I relive it every day. Every day - wishing I could rewrite the past - I relive the day I came to this country where I have known nothing but pain" (101). Probing deeper into Freud's perspective, it becomes clear that, for him, melancholia involves a "pathological tendency to denythereality of this loss" (Ruti 2005, 637-660) and, consequently, the melancholic's inability to mourn or grieve prevents him/her from future progress. This contrasts with Ranjana Khanna's concept of melancholia that "acts toward the future" because "the hope for a better persists" in the melancholic (2006). Butler's critique of Freud's concept of melancholia is also based on the fact that Freud tends to suggest that successful mourning is the sign of substitutability. She argues that rather than associating successful mourning with substitutability or with the act of forgetting the loved object, as Freud suggests, mourning must be taken as an "experience of transformation" because "one mourns when one accepts that by the loss one undergoes one will be changed, possibly forever"(2004, 21).

This hardly seems to be true in Kaukab's case. She is the one who remains unchanged throughout the novel. She 
neither progresses towards the future nor shows any willingness to,as Butler puts it, submit to a transformation. In other words, as Waterman suggests, Kaukab demonstrates "the sort of enclave mindset which hopes to guarantee a fixed notion of identity rather than consider identity as an ongoing process" (2010, vol. 2, 21). Whereas Freud's melancholic subject fails to mourn, Kaukab does mourn but her mourning does not entail "the progressive serving of affective ties to what has been lost so as to free the subject to direct its love and attention to new objects and endeavours" (Ruti 2005, 639). It might be assumed that Kaukab's efforts to establish a good relationship with her children are the symptoms of redirecting her love for the lost country; but she utterly fails in this. In fact, as Freud suggests and Ruti argues: "[s]uch objects, which often take on a larger-than-life meaning and magnificence, demand the individual's loyalty so intensely that disavowal becomes impossible" (639). Mah-Jabin's marriage to her cousin in Pakistan is one of the ways Kaukab may prove her loyalty to her own community in Pakistan; but in doing so, she becomes estranged from her children who blame their mother for destroying their lives. As MahJabinsays: "She has harmed everyone of us" (302).

Abraham and Torok's discourse on mourning and melancholy helps to situated his melancholic state of Kaukab in relation to "hostile external forces". According to Abraham and Torok:

Melancholics cherish the memory as their most precious possession, even though it must be concealed by a crypt built with the bricks of hate and aggression. It should be remarked that as long as the crypt holds, there is no melancholia. It erupts when the walls are shaken, often as a result of the loss of some secondary love-object who had buttressed them. Faced with the danger of seeing the crypt crumble, the whole of the ego becomes one with the crypt, showing the concealed object of love in its own guise (1994, 136).

Kaukab is cocooned in her limited world of home where her life revolves around her husband and children after she migrates to the Desert of Loneliness. After the loss of her primary love-object - her homeland - Kaukab's children become her secondary love-objects. Despite their infrequent visits, Kaukab's life revolves around her children and she cherishes every visit of her children as well as memories of their childhood. According to Abraham and Torok's poetics of the crypt, as long as Kaukab's primary love-objects -her country and her religion remain secure from the disparaging remarks of her children, she manages to stay calm. In other words, "the gaping wound", of leaving her homeland, "opened long ago within the ego" of Kaukab and is "distinguished by a fantasmic and secret construction in place of the very thing from which, through the loss, the ego was severed." As a result of this construction, Kaukab's wound is "disguised" and "unspeakable, because to state it openly would prove fatal to the entire topography" (1994, 142). However, she fails to remain calm when she was humiliated by her secondary love-objects - her children. In a bitter encounter between mother and daughter on the issue of MahJabin's marriage, when Mah-Jabin rebukes her mother's beloved country and her sham tradition of cousin marriages, Kaukab becomes, in her daughter's words, "the most dangerous animal she'll ever have to confront" (111). Kaukabs laps Mah-Jabin, knocking her "off the chair" (112). The more Mah-Jabin reproaches her mother for "the socalled traditions that you have dragged into this country with you like shiton your shoes" (114), the more Kaukab goes mad with pain. Mah-Jabin accuses her mother for having being failed to save her daughter's life by not telling her that the life of women in Pakistani society is "hard because [they] have to run the house during the day and listen to [their] husband's demands in bed at night". She even impeaches her mother's wisdom for not only living her own life in despair but also forcing her daughter into the same life and "expecting a different result" (113). Kaukab receives another blow on her ego when Mah-Jabin says: "How fucking wise you are, Mother, such wisdom! Victory awaits all the beleaguered Pakistani women but what a price, Mother, two decades of your life wasted ... What a waste when instead of conniving for all these years you could just walk away" (114). At this stage, Kaukab's ego - which constitute her self-esteem as well as her tolerance towards the decadent West through love for her religion and country - begins to shake and we hear her melancholiccry: "Get away from me, you little bitch!" (114).

Likewise, Charag, referring to circumcision, scolds his mother for "the first act of violence done to [him] in the name of religion or social system . . . wonder[ing] if anyone has the right to do it" (320). Kaukab's ego is hurt again and she winces: "Why must you mock my sentiments and our religion like this?" (320). Ujala, too, reproaches his mother for poisoning him with holy salt on the advice of a cleric, mocking her religion that has given her and millions like her such false ideas. As a result of this humiliation at the hands of her own children, the crypt crumbles and Kaukab's ego becomes one with the love object: she realises that it was the biggest mistake of her life to come to this country - "a country where children are allowed to talk to their parents this way, a country where sin is commonplace" (324). Hence, Kaukab's ego "begins the public display of an interminable process of mourning" (Abraham and Torok 1994, 136). Her grief does not remain her private grief; it manifests itself as public grief which has affected not only her own life but her husband's as well as her children's lives.

This is how the grief of one generation transfers to the next generation. As Waterman observes with regards to Maps for Lost Lovers:

The parents' memories do not correspond at all to their children's lived experience, meaning that the parents' cultural map, created out of traumatic past and clung to out of a sense of familiarity and security, has done a great deal of harm to their children, which explains the parents 'abject, suicidal loss of hope at the end of the novel.(2010, 2:30).

It can be argued that Aslam intends to show that Kaukab's "narcissistic pre-occupation of melancholia" ultimately "moved into a consideration of vulnerability of others" (Butler 2004,30), in this case her children and her husband who, as a reaction to her melancholic longings for her love 
objects, have become more British than Pakistani, more Western than Muslim. Kaukab's children feel 'othered' in their own home. As a result of Kaukab's self-inflicted pain, intercultural conflicts take the shape of intra-cultural conflicts and her children refuse to entail any responsibility towards their roots. Realising his traumatic position in Dasht-eTanhai, Shamas understands that:

[f]aced with a loss of roots, and the subsequent weakening in the grammar of 'authenticity', we move into a vaster landscape. Our sense of belonging, our language and the myths we carry in us remain, but no longer as 'origins' or signs of 'authenticity' capable of guaranteeing the sense of our lives. They now linger on as traces, voices, memories and murmurs that are mixed in with other histories, episodes, encounters (Chambers 1994, 18-19). Unlike Shamas, Kaukab's traumatic sense of grief deprives her children of what Chambers calls a 'grammar of authenticity' since they belong neither 'here' nor 'there'. Nevertheless, completely disillusioned with their mother's sense of belonging and melancholic nostalgia, their state of un-belonging and confusion has made them think that the only way to "make cultural mobility and integration less traumatic" is to move "away from the absolutes and certitudes of fixed cultural identity and towards an identity which does not retreat from flexibility and negotiation" (Waterman 2010, 2:32). For example, Charagh's marriage to English girl Stella and Mah-Jabin's audacious step divorce from her Pakistani husband to live her own life in America. A similar phenomenon can be explained in The Wasted Vigil with reference to Casa and James who are willing to sacrifice their lives for their homelands and people. Set in Usha, a small town in northern Afghanistan, The Wasted Vigil is a story of a land and people ruled by terror the Taliban. The story revolves around three main characters: Marcus, Lara and David. Marcus - a Muslim convert and an English doctor widowed by the Taliban- after losing his wife Qatrina and his daughter Zameen, lives with the hope that one day he will find his lost grandson, Bihzad who he has never seen. Lara is a Russian woman who comes to Marcus' home, in search of her lost brother, Benedikt - a former Red Army soldier - after discovering some connection between Benedikt and Zameen. David - disillusioned with his job as a spy - is an American former CIA operative, who has also been in love with Marcus' daughter. He looks after Lara, with Marcus. By creating harrowing images of a war-ravaged landscape, Aslam portrays Afghanistan as a symbol of the utter brutality of the Taliban. It is a land where horrible things happen such as book burning, amputation, decapitation and death by stoning. In the midst of this gloominess, a glimmer of hope appears in the novel when Dunia and Casa begin to nurture feelings for each other. However, this glimmering hope soon fades when love comes in conflict with faith and Casa realises that he should not forget about his duty to his religion. Therefore, in case of Casa and Duniya, as with Marcus and Qatrina or David and Zameen, love is engulfed by war and duty to religion dominates when Casa's hostility towards the Americans ultimately plunges him into the depths of zealotry and he blows himself up along with David because he was trained in al Qaeda camps to hate the West-the infidels.

Set against the background of post-9/11 rhetoric of war on terrorism, the novel highlights the struggle of a young Afghan mujahid Casa against the US army that, in turn, is countering the terrorist activities of mujahidin in Afghanistan. James, US official is on this mission in Afghanistan. When analysed in terms of Abraham and Torok's poetics of the crypt, Casa's struggle of "love and hate"- that "results from some traumatic affliction and from the utter impossibility of mourning" - implies that his "aggression is not in fact primary; it merely extends the genuine aggression the object actually suffered earlier in the form of . . . disgrace, or removal" $(1994,136)$. It is not only Casa's religion that has been disgraced by the American infidels but there has also been a constant effort on their part to expel him and other mujahidin from their own country. Casa's melancholic state of mind is evident during his conversation with Duniya:

For reasons she doesn't understand he brings his hands forward and displays the palms. He thinks she can see something in his lifelines? But what he says next makes it clear that he is some one traumatized by the United States invasion:

'Ihate America'.

There is a deliberation before each of his words, which seem carefully chosen as a result. She has the feeling that he is searching for the stable and most direct bridge between his inner self and the world (318).

However, Casa's ego becomes a public display when his loved objects are degraded by James who expresses his anger against Islam and his country Afghanistan - a place, James believes, that nurtures "the children of the devil" like him. "They have no choice but to spread destruction in the world" (413). James, while addressing David, says: "We have a new kind of enemy, David. They are allowed to read the Koran at Guantanamo Bay, as their religious and human right. But have you read it? They don't need jihadi literature - they've got the Koran. Almost every other page is a call to arms, a call to slaughter us infidels" (292-293). As a result of this insult to his religion, Casa directs his aggression at the external world - the US army in Afghanistan - and he does not hesitate even to kill his own saviour, David. Afterall, he cannot "let someone obliterate Islam" (319).

Similar melancholic feelings reside in James when he tortures Casa or other Jihadists in Afghanistan. Being an American soldier, he has a duty to his nation and the people who lost their lives in the 9/11 attacks, "a national tragedy" (Jackson 2005, 32). When fulfilling the duty given to him by his State to expel the Taliban and to prevent their return, James feels justified in being cruel to mujahidin. Responding to criticism that the US army treated mujahidin and Taliban with cruelty, he argues: "why must the United States be the only one asked to uphold the highest standards? No one in the world is innocent but these Muslims say they are ... So until everyone admits that they are capable of cruelty - and not define their cruelty as just - there will be problems" (295). If analysed objectively, none of these three characters - James, Casa and Bihzad - feel guilty for their atrocities against 
innocent people. It is also in this context that Abraham and Torok's concept of melancholia is important; it provides a justification for not feeling guilty or ashamed of the worst things a melancholic subject may do-a concept that is not explained by Freud. As Abraham and Torok argue: "the more suffering and degradation the object undergoes (meaning: the more hepines for the subject he lost), the prouder the subject can be" $(1994,136)$. Taking on his mission to protect and defend his homeland from the terrorist attacks of al Qaeda suicide bombers, James feels proud in devastating the Afghan population because by attacking the World Trade Center, AlQaeda degraded his nation. Likewise, Casa and Bihzad are proud to have been jihadists because Allah has ordered them to fight against infidels who are abusing their religion. Lara says more or less the same thing about Stepan's pride in fighting for his country, irrespective of the massacres of innocent civilians that are his responsibility: "When it came to what he called his nation, his tribe, he too suffered from a kind of blindness: he saw what he wanted to. 'You think your principles are higher than reality'. He'd say to me" (391).

Butler's model of melancholia helps us to understand how our individual memories are framed by national consciousness and the grief which is generally considered to be private in fact "furnishes a sense of political community of a complex order" $(2004,22)$. Aslam's novels show that in diasporic environments, in particular, there is no clear line dividing public and private grief or individual and collective memory. Therefore, Casa's and James' melancholia is an expression of their respective nation's sorrow. Both are antagonistic towards each other. Casa being a jihadi is targeting the Americans who are responsible for killing of jihadists and Jamesis targeting Afghans because they are responsible for the deaths of innocent civilians in the 9/11 attacks. Each of them is suffering because of their respective nations' sorrow. What Aslam is trying to show is that their "suffering[s] can yield an experience of humility . . . of impressionability and dependence, and these can be come resources, if we do not 'resolve' them too quickly; they can move us beyond and against the vocation of the paranoid victim who regenerates infinitely the justifications for war" (Butler 2004, 149-150).

Accentuating the relationship posited here between individual and nation, Gilroy asserts that " $\mathrm{t}]$ hat memory of the country at war against foes who are simply, tidily, and uncomplicatedly evil has recently acquired the status of an ethnic myth. It explains not only how the nation remade itself through war and victory but can also be understood as a rejection or deferral of its present problems" $(2005,89)$. The obsession with love objects - in individual or collective memory-either in the form of religion or nationalism actually "institutionalize[s] the melancholic reaction" which entails only violence rather than "transforming paralyzing guilt into a more productive shame" that would be conducive to a state that is "no longer phobic about the prospect of exposure to either strangers or otherness" (Gilroy 2005, 99). Invoking Alexander and Mitcherlich's concept to fmelancholia- which has its basis in German's reactions to the death of Hitler Gilroy situates his discussion in post-9/11 Britain and its "failure to appreciate the brutalities of colonial rule enacted in their name and to their benefit, to understand the damage it did to their political culture at home and abroad" $(2005,99)$. However, the overarching argument is relevant to the global scenario of contemporary power relations. The Wasted Vigil attempts to draw our attention to US imperial ventures, its interference and its dire consequences in countries like

Afghanistan and Pakistan. As Marcus says bitterly that " $[\mathrm{t}] \mathrm{he}$ entire world...had fought in this country, had made mistakes in this country, but mistakes had consequences and he didn't know who to blame for those consequences. Afghanistan itself, Russia, the United States, Britain, Arabia, Pakistan?" (40). Is this also not a reality that "the west was involved in the ruining of this place. . There would have been no downfall if this country had been left to itself by those others" (87). There is no denial of the fact, as also highlighted by Gilroy in the European context, that the US not only fails to admit the harm it has done in parts of the world, whether Afghanistan, Iran or Japan, but has also played a significant role in inculcating xenophobia among Americans and Europeans against Muslims through the media based propaganda of war on terrorism as well as concealing the facts from its own public. Hertsgaardre ports: During the military campaigns, the Pentagon's refusal to allow reporters to accompany troops in Afghanistan, and the practice of embedding reporters in the Iraq operation, was a blatant attempt to censor information reported during the fighting. When a Washington Post war correspondent tried to investigate civilian casualties in a village in Afghanistan, he was prevented at gunpoint by American troops from reaching the site (Jackson 2005, 170).

This is what Marcus says to Lara: "Through stories we judge our actions before committing them" (87); the stories that made nations; the stories which create stereotypes. James' anxiety to know about Casa reflects the construction no fnarratives of terror through "the language of threat and danger [that] saturates the discourse of the "war on terrorism", since the September 11 attack (Jackson 2005, 95).

When a refusal to mourn hinders and retards the subject's and the nation's progression in to the future, the act of mourning "despite our differences in location and history...appeal[s] to a "we," and teaches us "what it is to have lost somebody. Loss has made a tenuous 'we' of us all" (Butler 2004, 20). In The Wasted Vigil, Marcus and Lara despite their losses, tend to submit to transformation without forgetting the loved object. Marcus' loss is inseparable from his being; his lost hand and ruined home are constant reminders of his wife's tragic death, ultimately making depression and despair his permanent fate; yet, his effort to find his grandson makes him a futurist. Similarly, Marcus urges Lara to "go back and take the charge of these matters intelligently. You must delve deeper into Stepan's death, try to discover what your country's government and your country's army is doing" (417). This is how "readers are encouraged to consider in what ways memory, melancholia and mourning might be put at the service of a more inclusive conception of national and global communities" (Moore 2009, 17). 


\section{References}

Abraham, N and Torok. M. (1994). The Shell and the Kernal: Renewals of Psychoanalysis. Ed. and trans. Nicholas T. Rand. London: The University of Chicago Press.

Aslam, N. (2004). Maps for Lost Lovers. London: Faber and Faber Limited.

---, (2008). The Wasted Vigil. London: Faber and Faber Ltd.

Butler, J. (2004). Precarious Life: The Powers of Mourning and Violence. London: Verso.

Chambers, I. (1994). Migrancy, Culture, Identity. London: Routledge. Gay, P, ed. (1995). The Freud Reader. London: Vintage.

Gilroy, P. (2005). Postcolonial Melancholia. New York: Columbia University Press

Jackson, R. (2005). Writing the War on Terrorism: Language, Politics and Counter Terrorism. Manchester: Manchester University Press.

Khanna, R. (2006). Post-Palliative: Coloniality's Affective Dissonance. Postcolonial Text. 2.1.

Moore, L. (2009). British Muslim Identities and Spectres of Terror in Nadeem Aslam's Maps for Lost Lovers. Postcolonial Text $5.2: 17$.

Ruti, M. (2005). From Melancholia to Meaning: How to Live the Past in the Present. Psychoanalytic Dialogues 15.5: 637660.

Waterman, D. (2010). Memory and Cultural Identity: Negotiating Modernity in Nadeem Aslam's Maps for Lost Lovers. Pakistaniaat: A Journal of Pakistan Studies 2.2: 1835 